\title{
Higher production of $Y$-aminobutyric acid (GABA) by co-fermentation lactic acid bacteria with Rhus verniciflura extract
}

\author{
Young-Jun Jeon ${ }^{1}$, Yun-Geum-Sang Gwak ${ }^{1}$, Sam-Pin Lee ${ }^{1,2 *}$ \\ ${ }^{1}$ Department of Food Science and Technology, Keimyung University, Daegu 42601, Korea \\ ${ }^{2}$ The Center for Traditional Microorganism Resource (TMR), Keimyung University, Daegu 42601, Korea
}

\section{옻나무 추출물의 젖산균 혼합 발효를 통한 고농도 $\mathrm{Y}$-aminobutyric acid(GABA) 생산}

\author{
전영준 ${ }^{1}$ - 곽윤금상 ${ }^{1} \cdot$ 이삼빈 ${ }^{1,2 *}$ \\ ${ }^{1}$ 계명대학교 식품가공학과, ${ }^{2}$ 전통미생물자원개발 및 산업화연구센터
}

\begin{abstract}
Higher production of GABA by co-fermentation lactic acid bacteria with $R$. verniciflura extract. The pH and acidity of the RV extract were 4.49 and $0.13 \%$, respectively. The soluble solid and polyphenol contents were $0.52 \%$ and $5.77 \mathrm{mg} / \mathrm{g}$, and the reducing sugar content was $3.9 \mathrm{mg} / \mathrm{g}$. The RV extract $(15 \%$, v/v) was mixed with sucrose $(5 \%)$ and yeast extract (1\%). The mixture was fermented for 2 days at $25^{\circ} \mathrm{C}$ in the presence of Leuconostoc citreum S5. The second fermentation step involved the use of, Monosodium glutamate $(5 \%$, precursor) and skimmed milk (5\%). The second fermentation was carried out by Lactobacillus plantarum EJ2014 at $30^{\circ} \mathrm{C}$ over a period of 7 days. The $\mathrm{pH}$ of the co-fermented RV extract was 4.75 and the acidity was $0.99 \%$. The viable bacterial count for Leuc. citreum S5 and $L$. plantarum EJ2014 were $4.10 \log \mathrm{CFU} / \mathrm{mL}$ and $8.68 \log \mathrm{CFU} / \mathrm{mL}$, respectively. The complete bio-conversion of MSG produced GABA $(24.56 \mathrm{mg} / \mathrm{mL})$. The 2,2-diphenyl-1-picrylhydrazyl (DPPH) and 2,2'-azino-bis (ABTS) radical scavenging activity of the co-fermented $\mathrm{RV}$ decreased (from $3.89 \mathrm{mg} / \mathrm{mL}$ to $2.03 \mathrm{mg} / \mathrm{mL}$ (IC (C) $_{50}$ values) for DPPH; from $16.03 \mathrm{mg} / \mathrm{mL}$ to $5.07 \mathrm{mg} / \mathrm{mL}$ (IC 50 $_{5}$ values) for $\mathrm{ABTS}$ ). In conclusion the novel co-fermentation of RV extract could provide multi-functional ingredients, including GABA and probiotics.
\end{abstract}

Key words : Rhus verniciflura, fermentation, $\gamma$-aminobutyric acid (GABA), lactic acid bacteria, probiotics

서 론

옻나무(Rhus verniciflura)는 옻나무과의 낙엽 교목이며, 원산지는 중국에서 히말라야에 걸친 지역이고, 한반도 각처 에서 자라거나 재배된다. 서늘한 기후에서 잘 자라며 높이는 $10 \mathrm{~m}$ 내외이고, 나무껍질은 회백색이며, 두껍고 껍질눈이 많 다. 일반적으로 수액을 채취하여 옻칠로 사용되거나, 가지와 줄기를 말려 한약재 및 식자재로서 닭과 오리 등을 조리할
때 첨가하여 먹어왔다(Jung, 1998). 최근 대한민국 산림청의 임업경영 실태조사 보고서에 따르면 2012년 대비 2016년 옻 의 판매액이 약 $50 \%$ 증가한 것으로 나타났으며, 옻에 대한 사람들의 관심이 꾸준히 증가하는 것을 알 수 있다.

지금까지 옻나무의 효능연구를 살펴보면 옻나무에서 추출 된 플라보노이드 성분이 항산화(Lee 등, 2002; Son 등, 2005), 항돌연변이(Park 등, 2004), 항염증(Lee 등, 2009; Lee 등, 2010) 효과가 있는 것으로 밝혀져 있으며, 또한 항균 효과와

*Corresponding author. E-mail : splee@kmu.ac.kr, Phone : +82-53-580-5554, Fax : +82-53-50-5729

Received 24 September 2020; Revised 27 October 2020; Accepted 29 October 2020.

Copyright (c) The Korean Society of Food Preservation.

This is an Open Access article distributed under the terms of the Creative Commons Attribution Non-Commercial License (http://creativecommons.org/licenses/by-nc/4.0) which permits unrestricted non-commercial use, distribution, and reproduction in any medium, provided the original work is properly cited. 
혈압 상승을 유도하는 효소 $\alpha$-glucosidase의 억제 효과(Kim 등, 2010) 등이 보고되어있다. 그러나 옻은 urushiol이라는 페 놀성 물질의 혼합물로 인해 흔히 '옻이 오른다'라고 알려진 접촉성피부염을 유발하기도 한다. 따라서 옻이 식품소재로 안전하게 활용되기 위해서 안전성 평가 등에 많은 시간이 소요 되었다. 최근 옻나무 추출액이 식품소재로 안전하게 사용되기 위해서 천연발효 방법이 적용되었으며, 옻닭용 식품소재로 상 품화되었다(Kim 등, 2016; Lee 등, 2015). 옻의 안전성과 기능 성을 강화하려는 방법으로 발효기술은 많은 가능성을 가지고 있으며, 특히 probiotic 젖산균을 이용한 옻의 젖산균 발효를 통해서 기능성 물질이 강화된 고부가가치의 소재 개발에 관한 연구는 미비한 실정이다.

천연물에 존재하는 기능성 물질인 gamma aminobutyric $\operatorname{acid}(\mathrm{GABA})$ 는 비단백질 아미노산의 한 종류로서 발아 현미 등에 미량 존재한다(Choi 등, 2004). 특히, GABA는 동물의 뇌나 척수에 존재하는 신경전달 억제물질로서 작용하면서 기 억력 증진, 불면증, 항 스트레스, 항우울 등의 효능이 보고되 었다(Oh, 2005; Park, 2010). 일본에서는 식품, 화장품과 같 은 다양한 분야에서 기능성 물질로 활용되고 있으며 최근 한 국에서는 미생물 생산 $\mathrm{GABA}$ 를 초콜릿 등에 사용하고 있다. $\mathrm{GABA}$ 는 앞으로 기능성 소재로서 식품, 건강기능식품 및 화 장품 산업에 널리 사용될 것으로 판단된다. 현재 $\mathrm{GABA}$ 의 생 산은 젖산균을 이용하여 다시마 추출물 등에서 생산되고 있 으며(Lee, 2009), GABA 생산 균주인 L. plantarum은 식품의 약품안전처에서 인정하는 probiotics 균주로 보고되었다.

따라서 본 연구에서는 독성이 제거되어 식품소재로 활용되 고 있는 옻나무 추출액을 사용하여 유용 젖산균을 활용한 혼 합 발효기술을 최적화함으로써 GABA, probiotics 등의 기능 성 물질들을 강화하고 고부가가치 기능성 소재를 개발하고자 한다.

\section{재료 및 방법}

\section{재료}

본 실험에 사용한 옻나무 추출물(Rhus verniciflura extract) 는 옻가네 식품(Chungbuk, Korea)에서 구매하여 사용하였 다. 젖산발효 시 $\mathrm{GABA}$ 생성을 위하여 첨가한 부원료인 monosodium L-glutamate(MSG)와 glucose는 각각 Cheiljedang(Seoul, Korea), Samayang(Seoul, Korea)에서 구매하 였으며, skim milk와 yeast extract는 각각 서울우유(Seoul, Korea), Choheung(Gyeonggi, Korea)에서 구매하여 사용하 였다. MRS broth는 Difco ${ }^{\mathrm{TM}}$ 사의 제품을 구매하여 사용하였 고, 그 외 실험에 사용된 시약은 특급이상 시약들을 구매하여 사용하였다.

\section{사용 균주 및 starter 제조}

1차 젖산균 발효를 위한 Leuconostoc citreum $\mathrm{S} 5(\mathrm{KCCM}$ $10778 \mathrm{P})$ 균주는 김치에서 분리하여 미생물보전센터에서 기 탁하였다. MRS broth에 한 백금이 접종한 후 항온 배양기 (IS-971R, JeioTech Co., Kimpo, Korea)에서 $25^{\circ} \mathrm{C}$, 24시간 정치 배양하여 스타터로 사용하였다.

$\mathrm{GABA}$ 를 생산하는 2차 발효에 사용된 젖산균은 Lactobacillus plantarum EJ2014(KCCM 11545P)로 L. plantarum EJ2014 는 쌀겨(울진, 정미소)에서 분리된 균주로서 한국미생물보존 센터에 기탁하였다. 젖산균을 위한 스타터 배양액은 MRS agar plate에서 $30^{\circ} \mathrm{C}, 48$ 시간 배양한 균주를 MRS broth에 한 백금이 접종한 뒤 항온배양기(IS-971R, JeioTech Co.)에서 $30^{\circ} \mathrm{C}, 24$ 시간 배양하여 스타터로 사용하였다.

\section{수분 및 고형분 함량 측정}

수분 및 고형분 함량은 $105^{\circ} \mathrm{C}$ 에서 상압가열건조시켜 감소 하는 양을 수분함량으로 측정하였다.

\section{생균수 측정}

생균수는 발효물 $1 \mathrm{~g}$ 에 멸균수 $9 \mathrm{~mL}$ 를 첨가하여 10 배 희 석법을 이용하여 희석된 것을 배지에 $20 \mu \mathrm{L}$ 씩 도말 후 배양 한다. Leuconostoc citreum S5는 nutrient agar plate(Sigma Chemical Co., St. Louis, MO, USA)에서 $25^{\circ} \mathrm{C}$, Lactobacillus plantarum EJ2014는 MRS agar plate(Sigma Chemical Co.) 에서 $30^{\circ} \mathrm{C}$ 각각 48 시간 항온배양기에서 배양한 후 생균수를 $\log \mathrm{CFU}$ (colony forming unit) $/ \mathrm{mL}$ 로 나타내었다.

\section{$\mathrm{pH}$ 및 산도 측정}

$\mathrm{pH}$ 는 $\mathrm{pH}$ meter(Digtal $\mathrm{pH}$ meter 420A+, Thermo Orion, Beverly, MA, USA)로 측정하였다. 적정 산도는 시료를 0.1 $\mathrm{N} \mathrm{NaOH}$ 를 이용하여 $\mathrm{pH}$ 8.3까지 적정한 소비량을 젖산 함량 $(\% \mathrm{v} / \mathrm{v})$ 으로 환산하였다.

\section{총폴리페놀 함량측정}

AOAC 법(Chung, 2014)을 이용하여 총폴리페놀 함량을 측정하였다. 추출물을 농도별로 희석하여 Folin 시약(원액을 2 배 희석한 액)을 첨가하여 3 분간 반응시킨 후 $10 \% \mathrm{NaCO}_{3}$ 용액을 가해 반응하였다. 반응물의 흡광도를 micro plate reader(Epoch Biotek Instrument Inc., Winooski, VT, USA)를 사용하여 $700 \mathrm{~nm}$ 에서 측정하였다. 표준물질로는 gallic acid 를 각각 $0,20,40,60,80,100 \mu \mathrm{g} / \mathrm{mL}$ 가 되도록 표준용액을 만들었으며, 흡광도를 측정하여 표준 곡선을 작성, 값을 산출 하였다. 


\section{유리당 함량 측정}

혼합 발효된 옻나무 추출물의 발효 시간에 따른 유리당 함 량을 HPLC system(Knauer K-501 system, Triad scientific Inc., Manasquan, NJ, USA)을 사용하여 측정하였다. 발효액 을 $0.45 \mu \mathrm{m}$ syringe filter로 여과 후 $20 \mu \mathrm{L}$ 를 $\mathrm{HPLC}$ 분석용 시료로 사용하였다. HPLC 분석 시 검출기는 RI detector (Knauer K-2301, Triad scientific Inc.)을 이용 하였으며, 당 분석 전용 column NH2P-50 4E 4.6×250 mm(Shodex Co., Tokyo, Japan)을 이용 mobile phase는 $75 \%$ acetonitrile을 사 용하였다. 유속은 $1.0 \mathrm{~mL} / \mathrm{min}$ 의 속도로 맞추어 측정하였다 (Yoon과 Lee, 2019).

\section{무기질 함량 분석}

옻나무 추출물의 무기질을 식품공전(Ministry of Food and Drug Safety, 2014)에 따라 수행하였으며, 무기질 $\mathrm{Na}, \mathrm{Ca}, \mathrm{K}$, $\mathrm{Fe}, \mathrm{P}, \mathrm{Mg}, \mathrm{Mn}$ 의 함량은 건식분해법에 따라 시험용액 제조 후 ICP-OES로 측정하였다. 시료를 균질화한 뒤 $10 \mathrm{~g}$ 을 회화 용기에 취하고 그 후 탄화시킨 시료를 $550-600^{\circ} \mathrm{C}$ 에서 회백색 이 될 때까지 회화시켰다. 방랭 과정을 거친 뒤 염산 $10 \mathrm{~mL}$ 를 첨가하여 수욕 상에서 완전히 증발, 건조하였다. 건조된 고형분에 염산 $10 \mathrm{~mL}$ 를 다시 첨가 후 가열하여 $50 \mathrm{~mL}$ 정용 플라스크에 여과하였다. 불용물질은 여지와 함께 사용했던 회화 용기에 옮겨 건조 후 다시 회화하였다. 이때 남은 회분 을 증류수로 적신 뒤 염산 $2 \mathrm{~mL}$ 를 가해 증류수 $5 \mathrm{~mL}$ 로 희석 하여 수욕 상에서 가열하였다. 여과된 용액을 앞의 $100 \mathrm{~mL}$ 메스플라스크에 채워 증류수를 가하여 $100 \mathrm{~mL}$ 로 정용한 뒤 시험용액으로 사용, ICP-OES(Optima 7000 DV, Perkin Elmer Inc., Waltham, MA, USA)를 활용하여 무기질 함량을 측정하였으며, 이때 표준용액으로 얻어진 검량선을 이용하여 정량하였다(Choi, 2016).

\section{옻나무 추출물의 1 차 젖산균 발효}

옻나무 추출물 $15 \%$ 에 sucrose $5 \%$ 를 첨가하여 $121^{\circ} \mathrm{C}$ 에서 15 분간 멸균한 후 yeast extract $1 \%$ 를 첨가하였다. Luec. citreum $\mathrm{S} 5$ 스타터 $1 \%(\mathrm{v} / \mathrm{v})$ 를 접종하여 $25^{\circ} \mathrm{C}$ 항온배양기(IS-971R, JeioTech Co.)에서 2일간 정치배양 하였다.

\section{옻나무 추출물의 젖산균 혼합 발효}

GABA 및 probiotics 생산을 위한 젖산균 혼합 발효는 1차 발효가 진행된 발효물에 멸균한 skim milk 5\%와 MSG 5\% 를 첨가한 후 L. plantarum EJ2014 starter $1 \%(\mathrm{v} / \mathrm{v})$ 를 접종하 여 $30^{\circ} \mathrm{C}$ 항온배양기(IS-971R, JeioTech Co.)에서 7일간 2차 발효를 진행하였다. 그 후 발효물의 이화학적 분석을 시행하 였다.

\section{$\mathrm{GABA}$ 정성분석}

$\mathrm{MSG}$ 잔존량과 GABA 생성능 비교를 위한 표준물질로 $\mathrm{MSG} 0.5-1 \%$ 와 $\mathrm{GABA} \quad 0.5-1 \%$ 를 사용하였다. 전개 용매는 N-butyl alcohol $(\mathrm{mL})$ : acetic acid glacial $(\mathrm{mL}): \operatorname{water}(\mathrm{mL})$ 를 3 : 1 : 1 의 비율로 혼합하여 4 각 유리 chamber $(30 \times 25 \times 10)$, 실온에서 4시간 이상 포화시켰다. 시료를 2-5배 희석하고 $20,500 \times g$ 로 10 분간 원심 분리한 상등액을 TCL plate의 끝 에서 $20 \mathrm{~mm}$ 위치에 $2 \mu \mathrm{L}$ 를 점적하였고, sample 간격은 10 $\mathrm{mm}$ 를 유지하였다. 점적 후 TLC plate의 sample을 건조 시킨 후 전개하고, 전개가 끝난 TLC plate에 발색시약 $0.2 \%$ ninhydrin을 뿌리고, $105^{\circ} \mathrm{C}$ dry oven에서 3 분 동안 발색시킨 후 GABA spot을 확인하였다(Kwon과 Lee, 2017).

\section{$\mathrm{GABA}$ 정량분석}

아미노산 함량측정은 건조시킨 시료를 시험용액 $10 \mu \mathrm{L}$ 에 Borate buffer(I) $70 \mu \mathrm{L}$ 를 첨가하여 잘 섞어준 후 $\mathrm{AccQ}$ Flour reagent $20 \mu \mathrm{L}$ 를 추가하고, 1 분간 방치한 뒤 다시 잘 섞어주고 10 분간 가열한다. 10 분 뒤 실온에서 방랭시켜 유도 체화 하여 건조시킨 후 $\mathrm{A}$ 용매(140 mM NaHAc, $0.15 \%$ TEA, $0.03 \%$ EDTA, $6 \% \mathrm{CH}_{3} \mathrm{CN}, \mathrm{pH}$ 6.1)와 혼합하여 원심 분리(Micro21/21R, Thermo Fisher Scientific, Middlesex County, MA, USA)하였다. 상등액을 $0.45 \mu \mathrm{m}$ syringa filter 로 여과하여 분석 시료로 사용하였다. HPLC 분석 시스템은 Agilent 1290 infinity(Agilent Technologies, Inc., Santa Clara, CA, USA)이며, column(waters Nova-Park $\mathrm{C}_{18} 4 \mu \mathrm{m}$ $(3.9 \times 300 \mathrm{~mm})$ 은 $46^{\circ} \mathrm{C}$ 를 유지하면서 mobile phase 용매(140 $\mathrm{mM}$ NaHAc, $0.15 \%$ TEA, $0.03 \%$ EDTA $6 \%$ )를 사용하여 flow rate는 $1.0 \mathrm{~mL} / \mathrm{min}$ 유속으로 흘려주면서 $254 \mathrm{~nm}$ 에서 detector(HP 1100 Series, Agilent Technologies Inc.)로 측정 하였다(Kwon, 2017).

\section{항산화 활성 평가(DPPH, ABTS radical 소거활성 측정)}

옻나무 추출물 혼합 발효물의 free radical 소거 활성 측정 법은 안정한 자유 라디칼인 diphenyl-2-picrylhydrazyl(DPPH) (Sigma Co., Ltd.)에 대한 Blois 방법(Blois, 1958)에 따라 측 정하였다. 안정한 자유 라디칼인 $\mathrm{DPPH}$ 를 이용하여 일정량 의 시료 용액과 반응시켜 DPPH 라디칼이 감소하는 정도를 분광광도계(SpectraMax ABS Plus, Molecular Devices, San $\mathrm{Jose}, \mathrm{CA}, \mathrm{USA}$ )로 측정하여 간접적인 시료의 항산화 활성을 측정하였다. 시료 $160 \mu \mathrm{L}$ 를 메탄올에 녹인 뒤 $0.2 \mathrm{mM}$ $\mathrm{DPPH}$ 용액 $40 \mu \mathrm{L}$ 를 가하여 실온에서 30 분 반응 후 $517 \mathrm{~nm}$ 에서 흡광도를 측정하였다. 각 시료의 free radical 소거 활성 은 시료가 첨가되지 않은 대조 구의 흡광도를 $1 / 2$ 로 감소시 키는 시료의 농도인 $\mathrm{IC}_{50}$ 값으로 나타내었다. 이때 상대 활성 
의 비교를 위하여 대조군은 trolox를 사용하였다.

2,2-Azino-bis-3-ethylbenzothiazoline-6-sulfonic acid(ABTS) radical을 이용하여 항산화력 측정은 ABTS cation decolorization assay에 의한 방법( $\operatorname{Re}$ 등, 1999)을 일부 변형하여 측 정하였다. $7 \mathrm{mM} \mathrm{ABTS}$ 와 $2.45 \mathrm{mM}$ potassium persulfate를 최종 농도로 혼합 후 실온, 암소에서 24시간 동안 반응 후 ABTS radical을 인위적으로 생성시켰다. 이후 $732 \mathrm{~nm}$ 에서 흡광도 값이 $0.70( \pm 0.02)$ 이 되게 phosphate buffer saline (PBS, pH 7.4)로 희석 후 사용하였다. 희석된 용액 $180 \mu \mathrm{L}$ 를 원심분리 $(18,500 \times g, 10 \mathrm{~min})$ 후 취한 상등액 $20 \mu \mathrm{L}$ 를 가하 여 $200 \mu \mathrm{L}$ 를 맞춰준 후 정확히 1 분 동안 방치 후 $732 \mathrm{~nm}$ 에 서 흡광도(SpectraMax ABS Plus, Molecular Devices)를 측 정하였다.

\section{통계처리}

실험결과는 Statistic Package(IBM SPSS Version 25.0, SPSS Inc., Chicago, IL, USA)를 사용하였으며, 평균값과 표 준편차 $(m e a n \pm \mathrm{SD})$ 를 구한 후, 각 집단 간 평균 차이를 검증하 기 위하여 one-way ANOVA 분석 후 Duncan's multiple range test를 적용하였다. 결과에 대한 검증은 $\mathrm{p}<0.05$ 수준에 서 검증하였다(Gray와 Kinnear 2012).

\section{결과 및 고찰}

\section{옻나무 추출물의 이화학적 성분 및 무기질 함량}

업체에서 구매하여 시료로 사용될 옻나무 추출액의 이화 학적 특성을 분석하였다. 분석결과, $\mathrm{pH}$ 는 $4.49 \pm 0.02$ 로 측정 되었으며, 산도와 환원당은 각각 $0.13 \pm 0.01 \%, 3.9 \pm 0.04 \mathrm{mg} / \mathrm{g}$ 이었다. 고형분 함량은 $0.52 \pm 0.12 \%$ 이었으며, 폴리페놀 함량 은 $5.77 \pm 0.05 \mathrm{mg} / \mathrm{g}$ 으로 확인되었다.

무기질은 미생물 생육 및 대사조절에 필수적인 성분들이다. 옻나무 추출물의 무기질 종류 및 함량은 $\mathrm{Na}, \mathrm{Ca}, \mathrm{K}, \mathrm{Fe}, \mathrm{P}$, $\mathrm{Mg}, \mathrm{Mn}$ 의 $100 \mathrm{~g}$ 당 함량은 각각 $2.84,5.27,17.78,0.12,3.19$, $3.54,0.04 \mathrm{mg}$ 으로 측정되었으며, 이중 $\mathrm{K}$ 의 함량이 가장 많은 것으로 나타났다. 특히 $\mathrm{K}$ 의 경우 옻나무와 같이 한약재로 널 리 사용되고 있는 헛개나무 추출물(Yoon과 Lee, 2019)의 $8.98 \mathrm{mg} \%$ 에 비해 2배가량 높은 함유량을 나타내고 있으며, 황칠나무 추출물(Choi, 2016)의 Ca $0.10 \mathrm{mg} \%$, P $0.44 \mathrm{mg} \%$ 함유량보다 3-5배 이상 높은 함량을 나타내고 있다.

\section{옻나무 추출물의 1 차 젖산균 발효조건 최적화}

옻나무 추출물의 농도에 따른 젖산균 발효 특성을 분석하 기 위해서 옻나무 추출액을 최종 부피의 $50 \%, 25 \%, 15 \%$, $10 \%(\mathrm{v} / \mathrm{v})$ 가 되도록 희석한 후 $5 \%$ sucrose, $1 \%$ yeast extract
를 동일하게 첨가하여 1 차 젖산균 발효를 진행하였다.

\section{$\mathrm{pH}$ 및 산도 변화}

옻나무 추출액 $15 \%, 10 \%$ 조건에서 수행한 1차 젖산균 발 효에서 초기 $\mathrm{pH}$ 가 각각 $4.65,4.96$ 에서 1차 발효 2 일 차에 $3.69,3.81$ 로 옻나무 추출액 $50 \%, 25 \%$ 조건의 2 일 차 $\mathrm{pH}$ $4.36,4.29$ 보다 상대적으로 낮게 나타났다. $\mathrm{pH}$ 의 경우, 모든 조건에서 1 차 젖산균 발효가 진행됨에 따라 감소하였고, 옻 나무 추출물의 농도가 낮아질수록 $\mathrm{pH}$ 의 감소폭이 더 큰 것을 알 수 있었다. 산도 또한 1차 젖산균 발효 2일 차에 $50,25 \%$, $15 \%, 10 \%$ 로 희석한 모든 조건이 각각 $0.19 \%, 0.25 \%$, $0.62 \%, 0.52 \%$ 로 발효가 진행됨에 따라 증가한 것을 알 수 있었으며, 그중 $15 \%$ 까지 희석한 조건이 $0.62 \%$ 로 가장 높은 산도를 나타내었다(Table 1).

\section{생균수 변화}

1 차 젖산균 발효 시 접종되었던 Leuc. citreum의 생균수는 옻나무 추출물이 희석된 모든 조건(희석 10-50\%)에서 발효 0 일 차 평균 $7.04 \log \mathrm{CFU} / \mathrm{mL}$ 로 나타났으며, 발효 2일 차까 지 각각 $7.44,8.34,8.66,8.35 \log \mathrm{CFU} / \mathrm{mL}$ 로 증가하였다. 옻나무 추출액 $15 \%$ 첨가된 조건에서 $8.66 \log \mathrm{CFU} / \mathrm{mL}$ 로 가 장 많은 생균수가 확인되었다(Table 1).

결과적으로 1 차 젖산균 발효에서 옻나무 추출액의 농도가 젖산균의 생육에 영향을 미치고 있는 것으로 보이며, 가장 Leuconostoc의 활성이 뛰어난 조건은 $10 \%, 15 \%$ 조건이었다. 그러나 $10 \%$ 조건은 1 차 젖산발효 2 일 차에 활성이 급격히 떨어지는 것에 반해 $15 \%(\mathrm{v} / \mathrm{v})$ 조건에서는 Leuconostoc의 생 균수가 떨어지지 않고 활성이 유지되며, 산도가 $1 \%$ 이상까 지 증가되는 것으로 보아, 옻나무 추출물 $15 \%$ 조건이 1 차 젖 산균 발효에 최적 조건으로 판단하였다.

\section{MSG 농도별 젖산균 혼합 발효 특성}

젖산균 혼합 발효에서 전구물질로서 $\mathrm{MSG}$ (monosodium glutamate) 첨가에 따른 $\mathrm{GABA}$ 생산에 미치는 영향을 비교 하기 위하여 2 일간 진행된 1차 젖산균 발효물(옻나무 추출물 $15 \%)$ 에 $\mathrm{MSG}$ 를 각각 $3 \%, 5 \%$ 첨가하여 젖산균 혼합 발효를 수행하였다.

\section{$\mathrm{pH}$ 및 산도 변화}

젖산균 혼합 발효 0 일 차 $\mathrm{MSG} 3 \%, 5 \%$ 첨가 조건의 젖산 균 배양액의 $\mathrm{pH}$ 가 각각 $5.94,6.11$ 에서 2 차 발효 5 일 차에 다시 $4.52,4.84$ 로 감소하였다. $\mathrm{MSG}$ 가 $5 \%$ 첨가된 젖산균 배 양액의 $\mathrm{pH}$ 가 조금 더 높게 나타났다. 산도의 경우, $\mathrm{MSG} 3 \%$, $5 \%$ 첨가된 1 차 젖산균 발효액의 초기 산도가 각각 $0.34 \%$, 
Table 1. Effect of RV extract on the first fermentation by Leuc. citreum

\begin{tabular}{|c|c|c|c|c|}
\hline \multirow{2}{*}{$\begin{array}{l}\mathrm{RV}^{1)} \text { extract } \\
(\%)\end{array}$} & \multirow{2}{*}{$\begin{array}{l}1^{\text {st }} \text { Fermentation } \\
\text { time (days) }\end{array}$} & \multirow{2}{*}{$\mathrm{pH}$} & \multirow{2}{*}{$\begin{array}{c}\text { Acidity } \\
(\%)\end{array}$} & $\begin{array}{l}\text { Viable bacterial count } \\
\quad(\log \mathrm{CFU} / \mathrm{mL})\end{array}$ \\
\hline & & & & Leuc. citreum \\
\hline \multirow{3}{*}{50} & 0 & $4.49 \pm 0.03^{2 \mathrm{bb} 3)}$ & $0.12 \pm 0.01^{\mathrm{a}}$ & $6.79 \pm 0.01^{\mathrm{a}}$ \\
\hline & 1 & $4.47 \pm 0.03^{\mathrm{b}}$ & $0.18 \pm 0.01^{\mathrm{b}}$ & $7.01 \pm 0.03^{\mathrm{b}}$ \\
\hline & 2 & $4.36 \pm 0.01^{\mathrm{a}}$ & $0.19 \pm 0.02^{\mathrm{b}}$ & $7.44 \pm 0.01^{\mathrm{c}}$ \\
\hline \multirow{3}{*}{25} & 0 & $4.51 \pm 0.02^{\mathrm{c}}$ & $0.12 \pm 0.01^{\mathrm{a}}$ & $7.06 \pm 0.02^{\mathrm{a}}$ \\
\hline & 1 & $4.37 \pm 0.02^{\mathrm{b}}$ & $0.22 \pm 0.02^{\mathrm{b}}$ & $8.54 \pm 0.02^{\mathrm{b}}$ \\
\hline & 2 & $4.29 \pm 0.01^{\mathrm{a}}$ & $0.25 \pm 0.02^{\mathrm{c}}$ & $8.34 \pm 0.01^{\mathrm{c}}$ \\
\hline \multirow{3}{*}{15} & 0 & $4.65 \pm 0.01^{\mathrm{c}}$ & $0.09 \pm 0.03^{\mathrm{a}}$ & $7.01 \pm 0.02^{\mathrm{a}}$ \\
\hline & 1 & $4.01 \pm 0.04^{b}$ & $0.29 \pm 0.01^{\mathrm{b}}$ & $8.63 \pm 0.01^{\mathrm{b}}$ \\
\hline & 2 & $3.69 \pm 0.01^{\mathrm{a}}$ & $0.62 \pm 0.01^{\mathrm{c}}$ & $8.66 \pm 0.03^{b}$ \\
\hline \multirow{3}{*}{10} & 0 & $4.96 \pm 0.01^{\mathrm{c}}$ & $0.09 \pm 0.02^{\mathrm{a}}$ & $7.33 \pm 0.01^{\mathrm{a}}$ \\
\hline & 1 & $3.95 . \pm 0.01^{\mathrm{b}}$ & $0.44 \pm 0.02^{\mathrm{b}}$ & $8.76 \pm 0.01^{\mathrm{c}}$ \\
\hline & 2 & $3.81 \pm 0.02^{\mathrm{a}}$ & $0.52 \pm 0.03^{\mathrm{c}}$ & $8.35 \pm 0.04^{b}$ \\
\hline
\end{tabular}

${ }^{1)} \mathrm{RV}$ extract, Rhus vernicifluum extract.

${ }^{2)}$ Values are mean \pm SD $(\mathrm{n}=3)$.

3)-c- Different letters indicate significant difference at $\mathrm{p}<0.05$ by Duncan's multiple range test (The lowest value in the sample was expressed as a.).

$0.30 \%$ 로 나타났으나 큰 차이는 확인되지 않았다. 그러나 $\mathrm{MSG} 5 \%$ 첨가 조건의 경우 젖산균 혼합 발효 1 일 차에 산도 가 $1.39 \%$ 까지 상승하여 같은 시간대 $\mathrm{MSG} 3 \%$ 첨가 조건의 $1.19 \%$ 보다 높게 나타났다. 특히, MSG 3\% 첨가 조건의 경우 젖산균 혼합 발효 3 일에 산도가 $1.39 \%$ 까지 상승한 뒤 $1.06 \%$ 까지 감소하였으나, MSG 5\% 조건의 경우 젖산균 혼합 발효 3 일 차에 감소하기 시작하여 발효 5 일 차에 $0.86 \%$ 까지 상대 적으로 급격하게 감소하였다(Table 2).

\section{생균수 변화}

젖산균 혼합 발효 과정에서 생균수의 변화를 확인한 결과, Leuc. citreum의 경우 $\mathrm{MSG} 3 \%, 5 \%$ 첨가 조건에서 각각 젖 산균 혼합 발효 1 일 차에 $8.75,9.05 \log \mathrm{CFU} / \mathrm{mL}$ 에서 발효 5일 차에 각각 6.32, $6.58 \log \mathrm{CFU} / \mathrm{mL}$ 로 발효가 진행됨에 따라 혼합 발효 1 일에 가장 높은 생균수를 보인 후에 감소하 는 경향을 나타내었다.

또한, 젖산균 혼합 발효를 위해 접종된 L. plantarum은 혼 합 발효 1 일 차에 $\mathrm{MSG} 3 \%, 5 \%$ 첨가 조건에서 각각 9.43 , $9.13 \log \mathrm{CFU} / \mathrm{mL}$ 로 가장 높은 생균수 값을 보였으며, 발효 5일에 감소하여 각각 $8.60,8.67 \log \mathrm{CFU} / \mathrm{mL}$ 이었다. $L$. plantarum 역시 혼합 발효 1 일 차까지 생균수가 상승한 후 완만하게 감소하는 경향을 보였으며, Leuc. citreum보다 생균
수 감소폭이 적으면서 두 조건 모두 $8.60 \log \mathrm{CFU} / \mathrm{mL}$ 이상 유지되었다. 젖산균 생육에 초기 생균수에 관해서는 $\mathrm{MSG}$ 첨 가 농도에 따라 큰 차이가 나타나지 않았으나, 발효가 종료되 는 시점에서는 상대적으로 MSG 5\%가 첨가된 조건에서 더 높은 생균수가 유지되는 것으로 나타났다(Table 2).

이와 같은 L. plantarum의 최대 생균수 $9.43 \log \mathrm{CFU} / \mathrm{mL}$ 은 비슷한 $\mathrm{GABA}$ 생성 연구논문들과 비교해 보았을 때 $\mathrm{GABA}$ 함유 호상 요구르트(Lim과 Lee, 2014)의 $9.31 \log \mathrm{CFU} / \mathrm{mL}$, 오미자 추출물 발효액(Lee 등, 2016)의 $9.02 \log \mathrm{CFU} / \mathrm{mL}$ 보 다 약 $10-20 \%$ 이상 높은 수치로 상대적으로 풍부한 젖산균 이 생육된 것을 확인할 수 있었다.

\section{$\mathrm{GABA}$ 전환능}

1 차 젖산 발효물에 첨가되는 MSG 농도에 따른 GABA 생 산의 차이를 확인하기 위해 2차 젖산균 혼합배양액을 4 배 희 석한 뒤 thin layer chromatography를 통하여 정성분석을 진 행하였다(Fig. 1). MSG 첨가된 젖산균 혼합배양액은 혼합 발 효 3일부터 GABA 생성이 나타났으며, 발효 5일에 MSG 5\% 첨가된 조건에서 $\mathrm{MSG} 3 \%$ 첨가 조건보다 $\mathrm{GABA}$ spot보다 상대적으로 더 크게 나타났다. 그러나 전구물질인 $\mathrm{MSG}$ 의 농 도 증가에 따라 $\mathrm{GABA}$ 의 함량도 증가하지만 남아있는 $\mathrm{MSG}$ 의 양 또한 증가하였다. 따라서 고농도의 GABA 생산을 위해 
Table 2. Effect of MSG concentration on co-fermentation by Leuc. citreum and L. plantarum

\begin{tabular}{|c|c|c|c|c|c|}
\hline \multirow{2}{*}{$\begin{array}{c}\text { MSG content } \\
(\%)\end{array}$} & \multirow{2}{*}{$\begin{array}{l}\text { Co-fermentation } \\
\text { time (days) }\end{array}$} & \multirow{2}{*}{$\mathrm{pH}$} & \multirow{2}{*}{$\begin{array}{l}\text { Acidity } \\
(\%)\end{array}$} & \multicolumn{2}{|c|}{$\begin{array}{l}\text { Viable bacterial count } \\
\quad(\log \text { CFU } / \mathrm{mL})\end{array}$} \\
\hline & & & & Leuc. citreum & L. plantarum \\
\hline \multirow{4}{*}{3} & 0 & $5.94 \pm 0.03^{1) \mathrm{d} 2)}$ & $0.34 \pm 0.01^{\mathrm{a}}$ & $5.14 \pm 0.03^{\mathrm{a}}$ & $4.89 \pm 0.02^{\mathrm{a}}$ \\
\hline & 1 & $4.39 \pm 0.02^{\mathrm{b}}$ & $1.19 \pm 0.01^{\mathrm{c}}$ & $8.75 \pm 0.02^{\mathrm{d}}$ & $9.43 \pm 0.02^{\mathrm{c}}$ \\
\hline & 3 & $4.36 \pm 0.01^{\mathrm{a}}$ & $1.39 \pm 0.03^{\mathrm{d}}$ & $8.47 \pm 0.01^{\mathrm{c}}$ & $8.62 \pm 0.01^{\mathrm{b}}$ \\
\hline & 5 & $4.52 \pm 0.03^{\mathrm{c}}$ & $1.06 \pm 0.02^{\mathrm{b}}$ & $6.32 \pm 0.01^{\mathrm{b}}$ & $8.60 \pm 0.04^{\mathrm{b}}$ \\
\hline \multirow{4}{*}{5} & 0 & $6.11 \pm 0.02^{\mathrm{d}}$ & $0.30 \pm 0.02^{\mathrm{a}}$ & $5.14 \pm 0.03^{\mathrm{a}}$ & $4.89 \pm 0.02^{\mathrm{a}}$ \\
\hline & 1 & $4.52 \pm 0.01^{\mathrm{a}}$ & $1.39 \pm 0.01^{\mathrm{d}}$ & $9.05 \pm 0.01^{\mathrm{d}}$ & $9.13 \pm 0.02^{\mathrm{d}}$ \\
\hline & 3 & $4.57 \pm 0.02^{\mathrm{b}}$ & $1.32 \pm 0.01^{\mathrm{c}}$ & $8.38 \pm 0.02^{\mathrm{c}}$ & $8.74 \pm 0.02^{\mathrm{c}}$ \\
\hline & 5 & $4.84 \pm 0.04^{\mathrm{c}}$ & $0.86 \pm 0.03^{\mathrm{b}}$ & $6.58 \pm 0.01^{\mathrm{b}}$ & $8.67 \pm 0.03^{\mathrm{b}}$ \\
\hline
\end{tabular}

${ }^{1)}$ Values are mean \pm SD $(\mathrm{n}=3)$.

2)a-d Different letters indicate significant difference at $\mathrm{p}<0.05$ by Duncan's multiple range test.

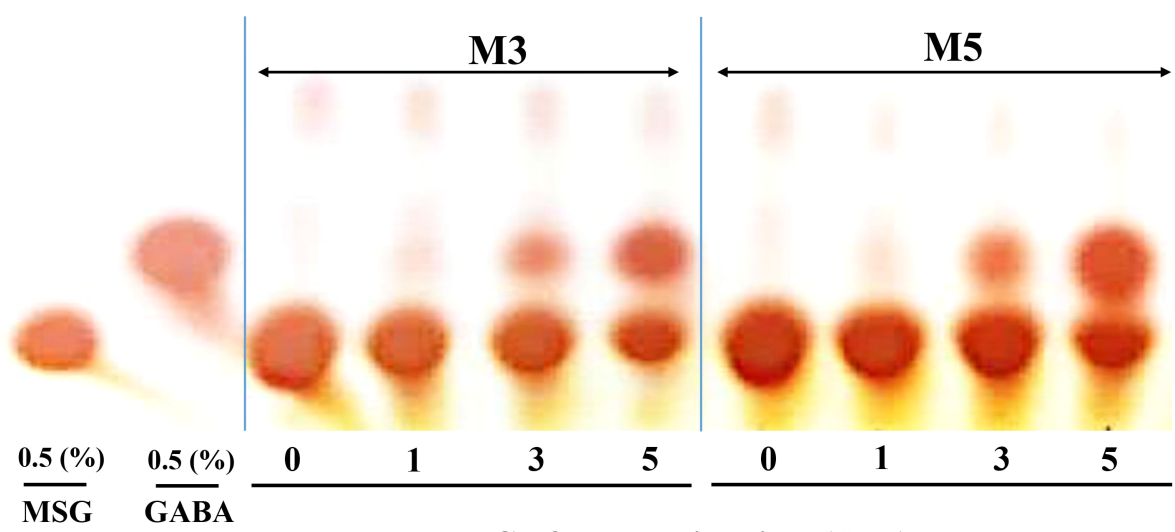

Co-fermentation time (days)

Fig. 1. Qualitative analysis of GABA conversion during co-fermentation with different MSG contents.

M3, added MSG 3\%. M5, added MSG 5\%.

서 전구물질 $\mathrm{MSG}$ 농도는 $5 \%$ 조건이 더 유리하며, $\mathrm{MSG}$ 를 $\mathrm{GABA}$ 로 모두 전환시키기 위해서는 발효 기간이 더 필요한 것으로 판단되었다. 본 연구에서 2 차 발효 3 일 차에 $\mathrm{GABA}$ 가 전환되기 시작하였는데, 이는 황칠나무 추출물의 혼합 발 효를 통한 $\mathrm{GABA}$ 생산연구에서 2차 발효 5일 차에 GABA가 전환되기 시작한 것(Choi, 2016)에 비하여 2일 이상 빠른 것 을 확인할 수 있었으며, 늙은 호박의 혼합 발효를 통한 GABA 생산연구(Park, 2018)에서도 혼합 발효 3일 차부터 본격적으 로 생산되는 것과 유사한 결과를 보여주었다.

\section{Skim milk 농도가 GABA 생산에 미치는 효과}

젖산균 혼합 발효에서 skim milk 농도가 GABA 생산에 미
치는 영향을 분석하기 위하여 2일간 진행된 1차 젖산균 발효 물에 skim milk를 $0 \%, 2.5 \%, 5 \%$ 농도별로 첨가하여 $\mathrm{GABA}$ 생성능을 비교·분석하였다.

\section{$\mathrm{pH}$ 및 산도 변화}

Skim milk 농도에 따른 $\mathrm{pH}$ 및 산도의 변화를 Fig. 2에 나 타냈다. 발효 초기 5.17이었던 $\mathrm{pH}$ 는 1차 젖산균 발효 2 일 차 3.77 까지 감소하였으며, 산도는 $0.16 \%$ 에서 $0.7 \%$ 까지 상승하 였다. 젖산균 혼합 발효 시에 skim milk $0 \%, 2.5 \%, 5.0 \%$ 첨 가로 인해 혼합 발효 1 일 차에 옻나무 추출물의 $\mathrm{pH}$ 는 증가하 면서 세 조건 모두 $\mathrm{pH} 4.65$ 정도를 나타내었으며, 산도의 경 우 각각 $1.25 \%, 1.20 \%, 1.14 \%$ 로 증가하면서 skim milk의 농 


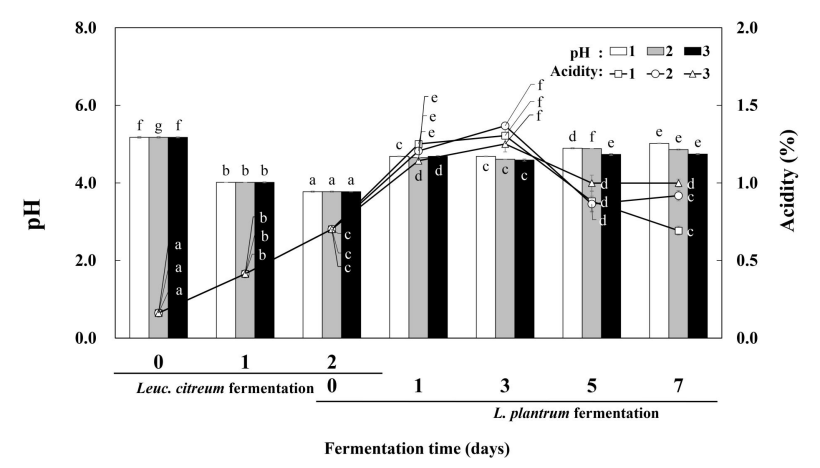

Fig. 2. Effect of skim milk content on $\mathbf{p H}$ and acidity during co-fermentation of Rhus verniciflura extract.

1 , skim milk $0 \%$; 2 , skim milk $2.5 \%$; 3 , skim milk $5 \%$.

Values are mean $\pm \mathrm{SD}(\mathrm{n}=3)$. Different letters indicate significant difference at $\mathrm{p}<0.05$ by Duncan's multiple range test (The lowest value in the sample was expressed as a).

도가 높을수록 산도가 약간 감소하는 경향을 보였다. 발효물 의 $\mathrm{pH}$ 는 혼합 발효 3 일 차 이후 큰 변화가 나타나지 않았으 나, 혼합 발효 5 일부터 모든 시료의 $\mathrm{pH}$ 가 증가하는 경향을 보였다. 산도는 혼합 발효 5 일 차에 급격히 감소하면서 skim milk 농도 증가에 따라 발효 7 일에 각각 $0.88 \%, 0.86 \%$, $0.99 \%$ 를 나타내었다. 이때 첨가된 skim milk의 농도가 낮을 수록 산도는 감소하는 경향을 보였으며, 최종 2차 젖산균 혼 합 발효물의 산도는 $1.0 \%$ 이하로 낮게 나타났다. 이는 일반적 인 젖산균 발효에서 발효성 당을 이용하여 젖산을 생성하면서 발효물의 $\mathrm{pH}$ 감소 및 산도가 증가하는 경향과는 상반되는 결 과를 나타내고 있다. 이는 젖산균 발효 시에 첨가되는 전구물 질인 MSG가 생물전환 되면서 생산되는 GABA의 buffer 작 용에 따른 현상으로 판단되었다(Komatsuzaki 등, 2005).

\section{생균수 변화}

Skim milk 농도에 따른 젖산균의 혼합 발효 중 생균수 변 화를 확인한 결과, Fig. 3에서처럼 2차 발효 1일 차까지 skim milk 농도에 따라 젖산균 생균수에 큰 차이는 나타나지 않았 다. Leuc. citreum 의 경우, 혼합 발효 1 일 차에 skim milk 농 도 증가에 따라 각각 $8.52,8.45,8.56 \log \mathrm{CFU} / \mathrm{mL}$ 까지 증가 한 후 감소하여 혼합 발효 7일 차에 모든 발효물에서 $4.0 \mathrm{log}$ $\mathrm{CFU} / \mathrm{mL}$ 이하로 낮아졌다. L. plantarum의 경우 혼합 발효 1일 차에 skim milk 농도와 관계없이 모두 생균수가 $9.0 \mathrm{log}$ $\mathrm{CFU} / \mathrm{mL}$ 이상까지 증가한 후 혼합 발효 7일 차까지 완만하 게 감소하면서 모든 발효물에서 생균수는 $8.0 \log \mathrm{CFU} / \mathrm{mL}$ 이상으로 나타내었다.

\section{$\mathrm{GABA}$ 전환능}

젖산균 혼합 발효 과정에서 skim milk 첨가 농도에 따른

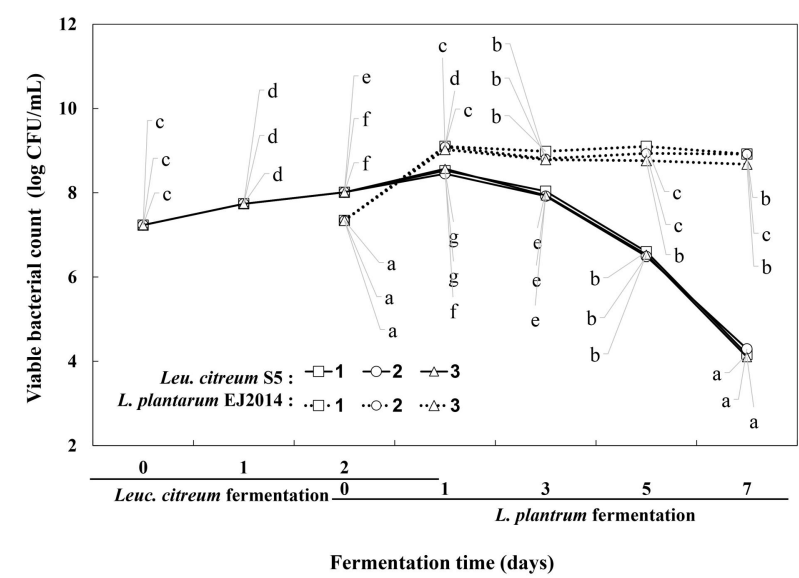

Fig. 3. Effect of skim milk content on viable bacterial counts during co-fermentation of Rhus verniciflura extract.

1, skim milk $0 \%$; 2 , skim milk $2.5 \%$; 3, skim milk $5 \%$. Values are mean \pm SD $(n=3)$. Different letters indicate significant difference at $\mathrm{p}<0.05$ by Duncan's multiple range test (The lowest value in the sample was expressed as a).

$\mathrm{GABA}$ 생성의 정도를 확인하기 위하여 발효물을 4배 희석한 뒤 thin layer chromatography를 통해 확인하였다(Fig. 4). 혼 합 발효물은 발효 3 일 차에서부터 $\mathrm{GABA}$ 전환이 시작되었으 며, $2.5 \%$ skim milk를 첨가된 발효물에서는 혼합 발효 7일에 $\mathrm{MSG}$ 가 전환되면서 $\mathrm{GABA}$ 가 생산되지만, MSG가 다소 남 아 있는 것으로 나타났다. 그러나 5\% skim milk를 첨가된 조 건에서는 $\mathrm{MSG}$ 대부분이 소진되면서 고농도 $\mathrm{GABA}$ 로 전환 된 것을 확인할 수 있었다.

결론적으로 젖산균 혼합 발효 과정에서 $5 \%$ skim milk가 첨 가된 조건이 $\mathrm{GABA}$ 전환능이 더 뛰어난 것으로 나타났다. 이 는 skim milk 첨가에 따른 유당 및 무기질을 포함한 영양성분 의 추가적인 공급이 젖산균 혼합 발효 과정에서 L. plantarum 의 세포 내 GABA 생산 효소인 glutamate decarboxylase의 활 성을 높이는 데 기여한다고 알려진 보고(Komatsuzaki 등, 2005)가 있으며, 이를 통해 skim milk가 그러한 역할을 한 것으로 판단되었다. 또한, 젖산균의 생육에 있어서 가장 중요 한 환경인자는 $\mathrm{pH}$, 질소원, 탄소원 그리고 온도라고 알려져 있는데(Choi 등, 2014), 이를 통해 2차 발효 시 고갈된 sucrose를 대신하여 skim milk가 부족한 탄소원을 보충하는 역할을 한 것으로 판단할 수 있었다.

따라서 옻나무 추출물을 이용한 젖산균 혼합 발효를 통해 서 $\mathrm{GABA}$ 전환의 최적화된 조건은 옻나무 추출물 $15 \%(\mathrm{v} / \mathrm{v})$, $1 \%$ yeast extract, $5 \%$ sucrose에서 1차 젖산균 발효를 진행한 후 추가로 $5 \% \mathrm{MSG}$ 와 $5 \%$ skim milk를 추가로 첨가하여 2차 젖산균 발효를 수행하는 것이 $\mathrm{GABA}$ 생성의 최적 조건으로 판단되었다. 


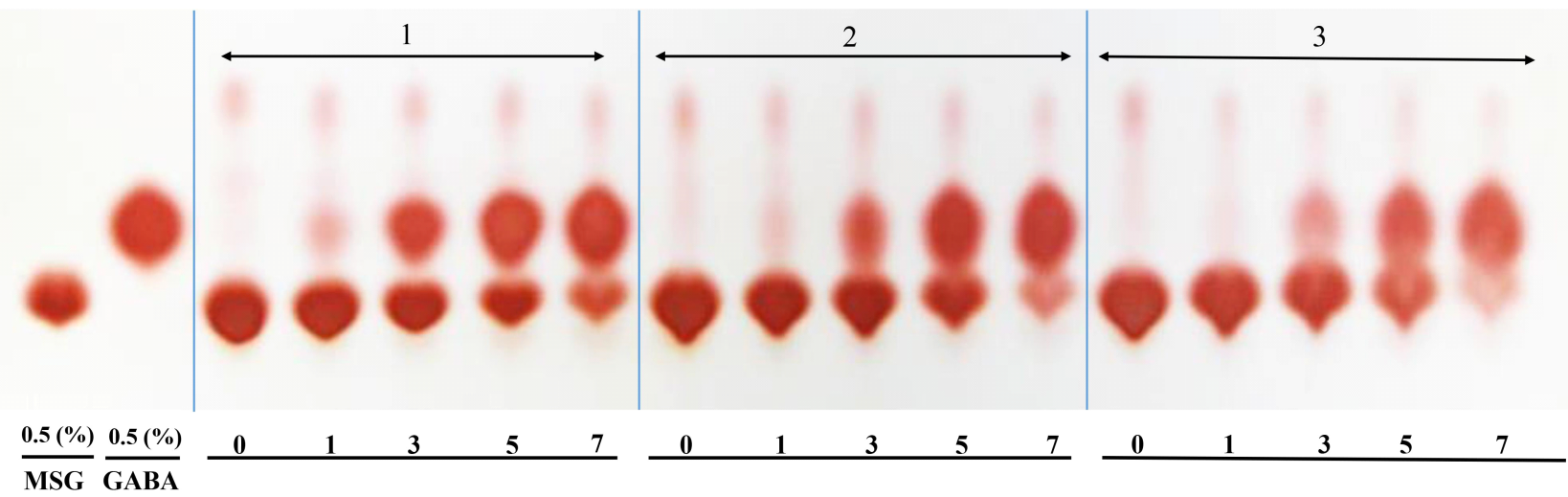

Co-fermentation time (days)

Fig. 4. Effect of skim milk content on GABA production during co-fermentation of Rhus verniciflura extract. , skim milk $0 \%$; 2 , skim milk $2.5 \%$; 3 , skim milk $5 \%$.

\section{발효물의 GABA 함량}

1 차 젖산균 발효 종료 후 MSG $5 \%$ 와 skim milk $5 \%$ 를 추가한 젖산균 혼합 발효 0 일 차 옻나무 혼합 발효물의 분 석결과, $36.57 \mathrm{mg} / \mathrm{mL}$ 의 glutamic acid를 나타내었다. 혼합 발효 7일 차에서 혼합 발효물의 분석결과, $0.10 \mathrm{mg} / \mathrm{mL}$ 의 glutamic acid와 $24.56 \mathrm{mg} / \mathrm{mL}$ 의 GABA가 확인되었다. 따 라서 발효 결과, 대부분의 glutamic acid가 GABA로 전환되 어 잔존 glutamic acid는 $0.01 \%$ 이하인 것을 확인할 수 있었 으며, $\mathrm{GABA}$ 전환율은 약 $57.8 \%$ 로 나타났다(Table 3). GABA 함량 $24.56 \mathrm{mg} / \mathrm{mL}$ 이라는 수치는 기존 발효를 통해 GABA 생산을 최적화한 연구들과 비교해 보아도 매우 높은 $\mathrm{GABA}$ 함량을 나타내고 있다. 헛개나무 추출물을 이용한 혼합 발효를 통해 GABA 생산을 최적화한 연구(Yoon과 Lee, 2019)에서는 약 $16.08 \mathrm{mg} / \mathrm{mL}$ 의 GABA를 전환하였는 데, 이와 비교하면 약 $50 \%$ 이상 더 높은 수치이며, 녹각추 출물의 젖산발효를 통한 GABA 생산 연구(Kwon, 2017)의 $\mathrm{GABA}$ 함량 $14.44 \mathrm{mg} / \mathrm{mL}$ 와 비교하면 $70 \%$ 이상 더 높은 수치이다. 이를 통해 기존의 미생물을 이용한 GABA 생산 연구들보다 더 높은 $\mathrm{GABA}$ 함량을 나타내고 있는 것을 확 인할 수 있었다.

Table 3. Changes in GABA contents during co-fermentation of Rhus verniciflura extract

\begin{tabular}{ccc}
\hline \multirow{2}{*}{ Free amino acid } & \multicolumn{2}{c}{ Co-fermentation (days) } \\
\cline { 2 - 3 } & 0 & \multicolumn{1}{c}{7} \\
\hline Glutamic acid $(\mathrm{mg} / \mathrm{mL})$ & $36.57 \pm 0.11$ & $0.17 \pm 0.02$ \\
GABA $(\mathrm{mg} / \mathrm{mL})$ & $0.10 \pm 0.03$ & $24.56 \pm 0.09$ \\
\hline
\end{tabular}

\section{옻나무 추출물 젖산 혼합 발효물의 유리당 함량 변화}

옻나무 추출물의 발효 동안 유리당(sucrose, mannitol, fructose) 함량의 변화를 HPLC를 통해 분석하였다(Fig. 5). 유리당 표준물질의 retention time은 sucrose $6.37 \pm 0.04 \mathrm{~min}$, mannitol $8.43 \pm 0.02 \mathrm{~min}$, fructose $12.77 \pm 0.05 \mathrm{~min}$ 으로 나타 났다. 1차 젖산발효 동안 발효 초기에 sucrose는 $5.71 \%$, mannitol은 $0.04 \%$, fructose는 $0.06 \%$ 로 발효 시 첨가하였던 sucrose를 제외하고는 $0.1 \%$ 미만의 유리당이 확인되었다.

1 차 젖산균 발효 1 일 차 sucrose는 소폭 감소하여 $4.20 \%$ 를 나타내었으며, fructose, mannitol은 각각 $0.06,0.40 \%$ 로 mannitol만 소폭 상승한 것으로 나타났다. 발효 2일 차 sucrose는 $3.91 \%$ 로 계속해서 감소하는 반면에 fructose, mannitol은 각 각 $1.12 \%$ 와 $0.66 \%$ 로 증가하는 추세를 보였다. 따라서 젖산

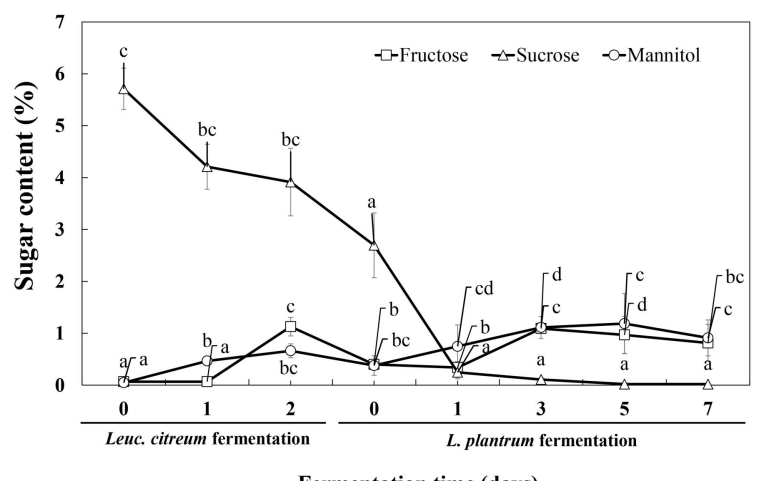

Fig. 5. Free sugar content in the Rhus verniciflura extract cofermented by Leuc. citreum and $L$. plantarum.

Value is a mean \pm SD $(n=3)$. Different letters indicate significant difference at $\mathrm{p}<0.05$ by Duncan's multiple range test (The lowest value in the sample was expressed as a). 
균 혼합 발효를 위한 1 차 젖산균 발효물의 발효성 당은 sucrose $4 \%$ 이상으로 나타났다.

젖산균 혼합 발효가 진행되면서 발효성 당인 sucrose는 감 소하여 혼합 발효 3 일 차에 sucrose는 $0.11 \%$ 로 대부분 소진되 었다. Fructose는 소폭 감소하지만 큰 변화는 보이지 않으며, mannitol은 계속해서 증가하여 fructose와 mannitol 각각 $1.09 \%, 1.11 \%$ 를 나타냈다. 혼합 발효 7 일 차에는 sucrose는 $0.02 \%$ 로 대부분 소진되었으며, fructose는 소폭 감소하여 $0.81 \%$ 를 나타내었다. 이를 통해 혼합 발효 1 일 차에 대부분의 sucrose가 분해되면서 fructose와 mannitolo이 생산되는 것을 확인할 수 있었다. 결론적으로 1 차 젖산균 발효 시에 첨가되 었던 sucrose는 발효 과정에서 대부분 이용되었다. 이는 Leuc. citreum 이 분비하는 sucrase 효소에 의해 fructose와 glucose로 분해된 것으로 보이며, mannitol이 생산된 것은 glucose를 활 용하여 Leuc. citreum이 세포 내 $\mathrm{NADH}$ 를 재순환함으로써 당 알코올인 mannitol을 생산한 보고(Otgonbayar 등, 2001)가 있 음으로 이러한 대사과정을 통해 생산된 것으로 사료된다.

\section{젖산 혼합 발효된 옻나무 추출물의 항산화 활성 평가}

옻나무 추출물의 항산화 활성을 측정하기 위해 $\mathrm{ABTS}$ 와 $\mathrm{DPPH}$ 의 radical 소거능을 측정하였다. $\mathrm{DPPH}$ 농도를 $50 \%$ 감소시키는 $\mathrm{IC}_{50}$ 으로 나타냈고 항산화제 중 하나인 trolox를 대조구로 사용하였으며, 측정 결과는 Table 4에 나타내었다. 옻나무 추출물의 발효 전 $3.89 \mathrm{mg} / \mathrm{g}$ 이었던 $\mathrm{IC}_{50}$ 값이 발효 후 $2.03 \mathrm{mg} / \mathrm{g}$ 으로 발효로 인해 소폭 radical 소거 활성이 증가 되었다. ABTS radical 소거능에 대한 시료의 영향은 $50 \%$ radical 소거율을 나타내는 $\mathrm{IC}_{50}$ 으로 나타내었으며, 대조구로 대표적인 산화방지제인 trolox를 사용하였고, 발효물과 trolox 의 $\mathrm{IC}_{50}$ 결과를 Table 5 에 표시하였다.

발효 전 옻나무 배지의 $\mathrm{IC}_{50}$ 값은 $16.03 \mathrm{mg} / \mathrm{g}$ 이었으나, 2차 발효가 7일까지 진행된 발효물에서는 $\mathrm{IC}_{50}$ 값이 $5.07 \mathrm{mg} / \mathrm{g}$ 으 로 감소하였다. 실제 상지나무와 같은 한방 소재도 발효 과정 을 거쳐 DPPH radical의 소거 활성 능이 $\mathrm{IC}_{50} 0.93 \mathrm{mg} / \mathrm{mL}$ 에 서 $0.23 \mathrm{mg} / \mathrm{mL}$ 로 증가한 사례가 있으며(Lee, 2017), 이를 통 해 옻나무 추출물도 발효를 통해 free radical 소거 능력이 증 대된 것으로 판단되었다.

\section{요 약}

옻나무 추출물에 젖산균의 생육을 위해 sucrose, yeast extract와 같은 탄소원과 질소원을 첨가 후 두 종류의 젖산균 을 단계적으로 배양하여 GABA가 강화된 옻나무 추출물 배 지 조건을 최적화하였다. 옻나무 추출물의 고형분 함량은 $0.52 \%$, 환원당은 $0.39 \mathrm{mg} / \mathrm{g}$, 총폴리페놀 함량은 $5.77 \mathrm{mg} / \mathrm{g}$ 으
Table 4. Scavenging effect of fermented Rhus verniciflura extract against DPPH

\begin{tabular}{cc}
\hline Sample & $\mathrm{IC}_{50}{ }^{1)}(\mathrm{mg} / \mathrm{g})$ \\
\hline None fermented RV extract $\left.{ }^{2}\right)$ & $3.89 \pm 0.04$ \\
Fermented RV extract & $2.03 \pm 0.02$ \\
Trolox $(\mu \mathrm{g} / \mathrm{g})$ & $40.48 \pm 0.06$ \\
\hline
\end{tabular}

${ }^{1)} \mathrm{IC}_{50}$, concentration required for $50 \%$ reduction of DPPH radical at 30 min after starting the reaction.

${ }^{2)} \mathrm{RV}$ extract, Rhus vernicifluum extract.

Table 5. Scavenging effect of fermented Rhus verniciflura extract against ABTS

\begin{tabular}{cc}
\hline Sample & $\mathrm{IC}_{50}{ }^{1)}(\mathrm{mg} / \mathrm{g})$ \\
\hline None fermented RV extract ${ }^{2)}$ & $16.03 \pm 0.08$ \\
Fermented RV extract & $5.07 \pm 0.05$ \\
Trolox $(\mu \mathrm{g} / \mathrm{g})$ & $50.28 \pm 0.04$ \\
\hline
\end{tabular}

${ }^{1)} \mathrm{IC}_{50}$, concentration required for $50 \%$ reduction of $\mathrm{ABTS}$ radical at 30
min after starting the reaction. ${ }^{2)} \mathrm{min}$ after starting the reaction.
${ }^{2}$ extract, Rhus vernicifluum extract.

로 나타났다. 젖산 혼합 발효된 발효물의 분석결과, 산도는 $0.99 \%, \mathrm{pH} 4.75$, 생균수는 Leuc. citreum S5, L. plantarum $\mathrm{EJ} 2014$ 가 각각 $4.10 \log \mathrm{CFU} / \mathrm{mL}, 8.68 \log \mathrm{CFU} / \mathrm{mL}$ 로 나타 났다. 유리당 분석결과, 혼합 발효 동안 sucrose는 $5 \%$ 에서 $0.02 \%$ 로 감소, mannitol과 fructose 각각 $1.09 \%, 1.11 \%$ 생산 되었다. 혼합 발효 7일 만에 $\mathrm{MSG}$ 대부분이 GABA로 전환된 것으로 나타났으며, HPLC 분석결과 $24.56 \mathrm{mg} / \mathrm{mL}$ 의 GABA 함량이 확인되었다. 혼합 발효물의 항산화 능은 실험결과 $\mathrm{DPPH}$ radical 소거능이 $\mathrm{IC}_{50}$ 값으로 발효 전 $3.89 \mathrm{mg} / \mathrm{mL}$ 에서 $2.03 \mathrm{mg} / \mathrm{mL}$ 로 감소하였으며, $\mathrm{ABTS}$ radical 소거능에서 $\mathrm{IC}_{50}$ 값의 경우 $16.03 \mathrm{mg} / \mathrm{mL}$ 에서 $5.07 \mathrm{mg} / \mathrm{mL}$ 로 감소하면서 항 산화 활성이 증가하는 것으로 나타났다. 결론적으로 Leuc. citreum S5와 L. plantarum EJ2014를 이용한 옻나무 추출물 의 젖산균 혼합 발효물은 기능성 물질 $\mathrm{GABA}$ 와 probiotics 등이 강화되어 고부가가치의 기능성 식품소재로서의 활용이 기대된다.

\section{감사의 글}

이 논문은 정부(교육부)의 재원으로 한국연구재단-대학혁 신지원사업의 지원을 받아 수행된 연구이며, 이에 감사드립 니다. 


\section{Conflict of interests}

The authors declare no potential conflict of interest.

\section{ORCID}

Young-Jun Jeon https://orcid.org/0000-0003-3725-5720

Sam-Pin Lee

\section{References}

Blois MS. Antioxidant determinations by the use of a stable free radical. Nature, 181, 1199-1200 (1958)

Choi HD, Park YK, Kim YS, Chung CH, Park YD. Effect of Pretreatment conditions on $\gamma$-aminobutyric acid content of brown rice and germinated brown rice. Korean J Food Sci Technol, 36, 761-764 (2004)

Choi JW. Optimized production of poly- $\gamma$-glutamic acid and $\gamma$-aminobutyric acid from Dendropanax morbifera extracts by Bacillus subtilis and Lactobacillus plantarum. MS Thesis, Keimyung University, Korea, $\mathrm{p}$ 14-21 (2016)

Choi JI, Kang SB, Park JH, Yoo SH, Yoon SS. Isolation and characterization of an immune-stimulating lactic acid bacteria from fermenting kimchi. Curr Top Lactic Acid Bac Probio, 2, 12-18 (2014)

Chung HJ. Comparison of total polyphenols, total flavonoids, and biological activities of black chokeberry and blueberry cultivated in Korea. J Korean Soc Food Sci Nutr, 43, 1349-1356 (2014)

Gray CD, Kinnear PR. IBM SPSS Statistics 19 Made Simple. Psychology Press, New York, NY, USA, p 149-187 (2012)

Jung NC. Biological activity of urushiol and flavonoids from Lac tree (Rhus verniciflua STOKES). Ph D Thesis, Chonnam National University, Korea, p 32-39 (1998)

Kim JS, Kwon YS, Chun WJ, Kim TY, Sun J, Yu CY, Kim MJ. Rhus verniciflua Stokes flavonoid extracts have anti-oxidant, anti-microbial and $\alpha$-glucosidase inhibitory effect. Food Chem, 120, 539-543 (2010)

Kim MJ, Kim HY, Kim DW, Heo GJ, Kim MS, Kim MK. Changes in biological functions composition during fermentation of Rhus verniciflua Stokes by Fomitella fraxinea. paper presented at 67 th annual meeting of the

Korean Society of Food Science and Nutrient, October 31-November 2, Jeju island, Korea, p 314-315 (2016)

Kwon SY. Production of $\gamma$-amino butyric acid (GABA) in old antler fermented by Lactobacillus plantarum and evaluation of bioactive property. MS Thesis, Keimyung University, Korea (2017)

Komatsuzaki N, Shima J, Kawamoto S, Momose H, Kimura T. Production of $\gamma$-aminobutyric acid (GABA) by Lactobacillus paracasei isolated from traditional fermented foods. Food Microbiol, 22, 497-504 (2005)

Lee JC, Lim KT, Jang YS. Identification of Rhus verniciflua Stokes compounds that exhibit free radical scavenging and anti-apoptotic properties. Biochim Biophys Acta, 1570, 181-191 (2002)

Lee BJ. Separation of GABA-producing lactic acid bacteria from traditional fermented foods and its use for the production of GABA from sea-tangle. MS Thesis, Gyeongsang National University, Korea, p 4-6 (2009)

Lee JD, Huh JE, Jeon GS, Yang HR, Woo HS, Choi DY, Park DS. Flavonol-rich RVHxR from Rhus verniciflua Stokes and its major compound fisetin inhibits inflammation-related cytokines and angiogenic factor in rheumatoid arthritic fibroblast-like synovial cells and in vivo models. Int Immunopharmacol, 9, 268-276 (2009)

Lee DS, Jeong GS, Li B, Park H, Kim YC. Antiinflammatory effects of sulfuretin from Rhus verniciflua Stokes via the induction of heme oxygenase-1 expression in murine macrophages. Int Immunopharmacol, 10, 850858 (2010)

Lee WJ, Kang JE, Choi HS, Jeong ST. Rapid manufacturing method of fermented lacquer to remove urushiol and preserve functional ingredients. Paper Presented at 66th Annual Meeting of the Korean Society of Food Science and Nutrient, August 24-26, Pyengchang, Korea, p 335 (2015)

Lee HS, Kwon SY, Lee SW, Lee SP. Production of fermented Omija (Schizandra chinensis) beverage fortified with high content of gamma-amino butyric acid using Lactobacillus plantarum. Korean J Food Preserv, 23, 326-334 (2016)

Lee DH. Antioxidant and anti-aging activities of fermented mulberry (Morus alba L.) branch extract. MS Thesis, Catholic University of Daegu, Korea, p 12-19 (2017)

Lim JS, Lee SP, Production of set-type yogurt fortified with 
peptides and $\gamma$-aminobutyric acid by mixed fermentation using Bacillus subtilis and Lactococcus lactis. Korean J Food Sci Technol, 46, 165-172 (2014)

Ministry of Food and Drug Safety. Health Functional Food Aeronautical Test Method. Jinhan M\&B, Seoul, Korea, p 232-291 (2014)

Otgonbayar GE, Eom HJ, Kim BS, Ko JH, Han NS. Mannitol production by Leuconostoc citreum KACC 91348P isolated from kimchi. J Microbiol Biotechnol, 21, 968-971 (2001)

Oh NR. Physiological characteristics of Lactobacillus crispatus RMK567 isolated from milk and optimization of GABA producing condition. MS Thesis, Sungkyunkwan University, Korea, p 12-20 (2005)

Park KY, Jung GO, Lee KT, Choi JW, Choi MY, Kim GT, Jung HJ, Park HJ. Antimutagenic activity of flavonoids from the heartwood of Rhus verniciflua. J Ethnopharmacol, 90, 73-79 (2004)
Park KS. Screening and identification of gamma-aminobutyric acid (GABA)-producing lactic acid bacteria isolates from kimchi. MS Thesis, Chungang University, Korea, p 11-22 (2010)

Park EJ. Optimized production of $\gamma$-aminobutyric acid and bioactive compounds from old pumpkin (Cucurbita moschata) by co-fermentation. MS Thesis, Keimyung University, Korea, p 23-40 (2018)

Son YO, Lee KY, Lee JC, Jang HS, Kim JG, Jeon YM, Jang YS. Selective antiproliferative and apoptotic effects of flavonoids purified from Rhus verniciflua Stokes on normal versus transformed hepatic cell lines. Toxicol Lett, 155, 115-125 (2005)

Yoon WG. Optimum production of $\gamma$-PGA and GABA in Hovenia dulcis extract by co-fermentation using Bacillus subtilis HA and Lactobacillus plantarum EJ2014. MS Thesis, Keimyung University, Korea, p 26-68 (2019) 